\title{
Występowanie zespołów bólowych kręgosłupa lędźwiowo-krzyżowego wśród personelu pielęgniarskiego
}

\author{
The occurrence of lumbosacral spine pain syndrome among \\ nursing staff
}

\author{
DOROTA WOLSKA', KAROLINA FILIPSKA ${ }^{2,3}$, BEATA HAOR ${ }^{4,5}$
}

\footnotetext{
${ }^{1}$ Oddział ogólnopsychiatryczny, Wojewódzki Szpital dla Nerwowo i Psychicznie Chorych w Świeciu

2 Koło Naukowe „Neuronauka” Zakład Pielęgniarstwa Neurologicznego i Neurochirurgicznego, Collegium Medicum im. Ludwika Rydygiera w Bydgoszczy

${ }^{3}$ Studia doktoranckie Zakład Pielęgniarstwa Neurologicznego i Neurochirurgicznego, Collegium Medicum im. Ludwika Rydygiera w Bydgoszczy

${ }^{4}$ Instytut Nauk o Zdrowiu PWSZ we Włocławku

5 Zakład Pielęgniarstwa Neurologicznego i Neurochirurgicznego, CM im. Ludwika Rydygiera w Bydgoszcz
}

DOI: http://dx.doi.org/10.21784/IwP.2018.016

ISSN: 2451-1846

\section{Streszczenie:}

Wstęp. Zespoły bólowe kręgosłupa zaliczane są do jednej z najczęstszych dolegliwości występujących w społeczeństwie. Problemy dotyczące przewlekłych dolegliwości ze strony narządu ruchu zwiększyły się do tego stopnia, że zasługują na miano choroby cywilizacyjnej.

Cel. Celem pracy jest analiza stopnia nasilenia bólu kręgosłupa w pracy pielęgniarek/pielęgniarzy. 
Wyniki. Wszystkie badane osoby stwierdziły zgodnie, że doświadczają dolegliwości bólowych kręgosłupa. Średnia ocena odczuwanego bólu według skali VAS wyniosła 4,97 punktu. Jako najczęściej występujący charakter bólu wskazano ból promieniujący - 46 osób, (33,3\% wszystkich zaznaczonych stwierdzeń). W dalszej kolejności zaznaczano ból rwący - 32 osoby $(23,2 \%)$ oraz ból przeszywający - 23 osoby $(16,7 \%)$. Wiek badanych oraz wykształcenie pozostawało $\mathrm{w}$ istotnej statystycznie korelacji $(\mathrm{p}<0,05)$ z wynikami odczuwanego bólu w skali VAS.

Wnioski. Dane epidemiologiczne wskazują, że dolegliwości związane z zespołami bólowymi kręgosłupa stanowią współcześnie jeden z głównych problemów medycyny. Do najbardziej narażonych grup zawodowych na występowanie dolegliwości bólowych kręgosłupa zaliczamy pielęgniarki/pielęgniarzy. Częsty powód bólu, który jest odczuwany przez pielęgniarki, stanowi osłabiony oraz nieprawidłowo przygotowany mięśniowo-więzadłowy aparat, dlatego tak istotna jest profilaktyka zespołów bólowych zwłaszcza w tej grupie zawodowej.

Słowa kluczowe: pielęgniarki, ból, skala VAS

\begin{abstract}
:
Introduction. Spinal pain syndrome is one of the most common complaints in society. Problems with chronic musculoskeletal complaints have increased to the point that they deserve to be called a civilization disease.
\end{abstract}

Aim. The aim of the study is to analyze the degree of spinal pain intensity in the nurses' work.

Results. All respondents stated that they experience spinal pain. The average assessment of perceived pain according to the VAS scale was 4.97 points. The most frequent type of pain was radiating pain - 46 people, (33.3\% of all marked statements). Subsequently, stabbing pain was marked 32 people $(23.2 \%)$ and piercing pain - 23 people $(16.7 \%)$. The age of the subjects and education remained in a statistically significant correlation $(\mathrm{p}<0.05)$ with the results of pain perception in the VAS scale.

Conclusions. Epidemiological data indicate that ailments associated with spinal pain syndromes are currently one of the main problems of medicine. The most vulnerable professional groups for the occurrence of back pain are nurses. A frequent reason for the pain that is experienced by nurses is a weakened and improperly prepared muscular-ligamental apparatus, 
which is why prevention of pain syndromes, especially in this professional group, is so important.

Keywords: nurses, pain, VAS scale

\section{Wstęp}

Zespoły bólowe kręgosłupa zaliczane są do najczęstszych dolegliwości występujących u człowieka. Uważa się, że współczynnik zachorowalności jest wyższy niż $w$ przypadku chorób układu sercowo-naczyniowego. Problemy dotyczące przewlekłych dolegliwości ze strony narządu ruchu zwiększyły się do tego stopnia, że zasługują na miano choroby cywilizacyjnej [1].

Dane epidemiologiczne pokazują że dolegliwości związane z zespołami bólowymi kręgosłupa stanowią współcześnie jeden z głównych problemów medycyny. W populacji światowej 75-85\% osób doznaje przynajmniej jednego incydentu bólowego odcinka lędźwiowo-krzyżowego podczas całego życia. Więcej niż u połowy osób, objawy lędźwiowo-krzyżowe znikają po około od 1-2 tygodni, lecz u 80-90\% osób całkowity zanik dolegliwości ustępuje po 8 tygodniach [2,3]. Wymienia się wiele przyczyn występowania dolegliwości bólowych kręgosłupa. Najczęściej pojawiają się one wskutek zmian zwyrodnieniowo-wytwórczych, które powodują podrażnienia zakończeń nerwowych struktur kręgosłupa [1].

Konstrukcja kręgosłupa jest bardzo wytrzymała na działania mechaniczne, lecz z upływem czasu pojawiają się dolegliwości, które mają związek ze zmianami zapalnymi lub też zmianami zwyrodnieniowymi, często z powodu niefizjologicznej postawy ciała urazu oraz również $\mathrm{w}$ związku $\mathrm{z}$ pracą zawodową. Prowadzi to do zmniejszenia przestrzeni zwanej fizjologiczną, w której znajduje się płyn mózgowo-rdzeniowy, pojawia się ucisk na rdzeń kręgowy oraz korzenie nerwowe. Występowanie zespołów bólowych kręgosłupa istotnie wpływa na pogorszenie odczuwanej jakości życia $[4,5]$. 
Celem pracy jest analiza stopnia nasilenia bólu kręgosłupa w pracy pielęgniarek/pielęgniarzy.

\section{Materiał i metody}

Badaną grupę stanowiło 50 pielęgniarek w wieku $\geq 18$ r.ż. zatrudnionych w oddziałach zabiegowych: chirurgii ogólnej, ortopedii oraz w oddziałach zachowawczych: neurologii, pediatrii, chorób wewnętrznych, obserwacyjno- zakaźnym, medycyny paliatywnej, rehabilitacji. Zdecydowana większość badanych to kobiety - 49 osób (98,0\%). Odnotowano tylko 1 mężczyznę pracującego na oddziale zachowawczym $(2,0 \%)$. Średnia wieku wyniosła nieco powyżej 46 lat. Ponad połowa respondentów, to mieszkańcy miasta - 34 osoby (68,0\%). Większość respondentów tj. 66,0\% deklarowała wykształcenie średnie, natomiast wykształcenie wyższe- 34\%.

Badania miały charakter anonimowy, dobrowolny, bezpłatny. W pracy wykorzystano kwestionariusz ankiety własnej oraz skalę VAS. Wszystkie obliczenia i ryciny wykonano przy użyciu programu Statistica 10.0 i arkusza kalkulacyjnego Microsoft Excel wykorzystując standardowe funkcje tego programu. Przyjęto poziom istotności $\mathrm{p} \leq$ 0,05 jako poziom istotny statystycznie. Współzależność pomiędzy dwiema zmiennymi, obliczono za pomocą współczynnik korelacji R Spearmana. Zastosowano również, nieparametryczny Test U Manna-Whitneya, do oceny różnic jednej cechy pomiędzy dwoma populacjami (grupami).

\section{Wyniki}

Wszystkie badane osoby, na obu oddziałach, stwierdziły zgodnie, że doświadczają dolegliwości bólowych kręgosłupaodpowiednio 16 pielęgniarek $\mathrm{z}$ oddziału zabiegowego i 34 z zachowawczego (Tabela 1). 
Tabela 1. Doświadczanie dolegliwości bólowych kręgosłupa przez badanych.

\begin{tabular}{|l|l|l|l|l|l|l|}
\hline & \multicolumn{2}{|l|}{ oddział } & \multicolumn{2}{l|}{ zachowawczy } & \multicolumn{2}{l|}{ razem } \\
\hline odpowiedź & liczba & $\%$ & liczba & $\%$ & liczba & $\%$ \\
\hline tak & 16 & 100,0 & 34 & 100,0 & 50 & 100,0 \\
\hline nie & 0 & 0,0 & 0 & 0,0 & 0 & 0,0 \\
\hline Razem & 16 & 100,0 & 34 & 100,0 & 50 & 100,0 \\
\hline
\end{tabular}

Źródło: wynik badań własnych

Ponad połowa badanych wskazała, że najczęściej odczuwany jest przez nich ból w odcinku lędźwiowym kręgosłupa - 30 osób (60,0\%), natomiast ból w odcinku krzyżowym kręgosłupa dotyczy20 osób (40,0\%). Na oddziale zabiegowym, większość respondentów wskazało na odcinek krzyżowy kręgosłupa - 11 osób (68,8\%), na oddziale zachowawczym większość respondentów skarżyła się na ból w odcinku lędźwiowym kręgosłupa - 25 osób (73,5\%) (Tabela 2).

Tabela 2. Odczuwanie dolegliwości bólowych przez badanych w zależności od odcinka kręgosłupa.

\begin{tabular}{|l|l|l|l|l|l|l|}
\hline oddział & \multicolumn{2}{l|}{ zabiegowy } & \multicolumn{2}{l|}{ zachowawczy } & \multicolumn{2}{l|}{ razem } \\
\hline $\begin{array}{l}\text { odcinek } \\
\text { kręgosłupa }\end{array}$ & liczba & $\%$ & liczba & $\%$ & liczba & $\%$ \\
\hline lędźwiowy & 5 & 31,3 & 25 & 73,5 & 30 & 60,0 \\
\hline
\end{tabular}




\begin{tabular}{|l|l|l|l|l|l|l|}
\hline krzyżowy & 11 & 68,8 & 9 & 26,5 & 20 & 40,0 \\
\hline Razem & 16 & 100,0 & 34 & 100,0 & 50 & 100,0 \\
\hline
\end{tabular}

Źródło: wynik badań własnych

Odpowiadając na pytanie o charakter odczuwanego bólu respondenci zaznaczali po kilka stwierdzeń. Łącznie od 50 osób odnotowano 138 odpowiedzi, średnio - 2,76 odpowiedzi. Na oddziale zabiegowym od 16 ankietowanych odnotowano - 41 odpowiedzi, średnio - 2,56 odpowiedzi, na oddziale zachowawczym od 34 badanych - 97 odpowiedzi, średnio - 2,85 odpowiedzi. Najczęściej osoby badane wskazywały, że ból ma charakter promieniujący - 46 osób $(33,3 \%$ wszystkich zaznaczonych stwierdzeń). W dalszej kolejności zaznaczano ból rwący - 32 osoby $(23,2 \%)$ oraz ból przeszywający - 23 osoby $(16,7 \%)$. W najmniejszym stopniu badani określali ból jako palący 10 osób $(7,2 \%)$. Na oddziale zabiegowym najczęściej respondenci wymieniali ból promieniujący - 14 osób (34,1\%) oraz rwący 10 osób $(24,4 \%)$. W najmniejszym stopniu wskazywali na ból ostry 1 osoba (2,4\%). Na oddziale zachowawczym najczęściej ankietowani wymieniali ból promieniujący - 32 osoby $(33,0 \%)$ oraz rwący 22 osoby $(22,7 \%)$. W najmniejszym stopniu badani wskazywali na ból kłujący - 6 osób $(6,2 \%)$. Żaden z respondentów nie wskazał na jedną cechę występującego bólu. Dwie cechy zaznaczyło - 21 osób (8/13), trzy cechy - 21 osób (7/14), cztery cechy - 7 osób (1/6) i pięć cech1 osoba $(0 / 1)$ (Tabela 3$)$.

Tabela 3. Charakter odczuwanego bólu przez badanych.

\begin{tabular}{|l|l|l|l|l|l|l|}
\hline oddział & \multicolumn{2}{|l|}{ zabiegowy } & \multicolumn{2}{l|}{ zachowawczy } & \multicolumn{2}{l|}{ razem } \\
\hline charakter bólu & liczba & $\%$ & liczba & $\%$ & liczba & $\%$ \\
\hline kłujący & 6 & 14,6 & 6 & 6,2 & 12 & 8,7 \\
\hline
\end{tabular}




\begin{tabular}{|l|l|l|l|l|l|l|}
\hline rwący & 10 & 24,4 & 22 & 22,7 & 32 & 23,2 \\
\hline ostry & 1 & 2,4 & 14 & 14,4 & 15 & 10,9 \\
\hline promieniujący & 14 & 34,1 & 32 & 33,0 & 46 & 33,3 \\
\hline przeszywający & 7 & 17,1 & 16 & 16,5 & 23 & 16,7 \\
\hline palący & 3 & 7,3 & 7 & 7,2 & 10 & 7,2 \\
\hline Razem & 41 & 100,0 & 97 & 100,0 & 138 & 100,0 \\
\hline
\end{tabular}

Źródło: wynik badań własnych

Najwięcej badanych odpowiedziało, że ból kręgosłupa w odcinku lędźwiowo-krzyżowym występuje kilka razy w miesiącu 24 osoby $(48,0 \%)$. Najmniej respondentów potwierdziło, że raz w tygodniu - 4 osoby $(8,0 \%)$. Na oddziale zabiegowym, najwięcej ankietowanych wskazało, że ma on miejsce kilka razy w miesiącu 10 osób $(62,5 \%)$. Nieliczna grupa badanych potwierdziła, że 2-3 razy w tygodniu lub raz w tygodniu - po 1 osobie (po 6,3\%). Na oddziale zachowawczym respondenci $\mathrm{w}$ największym stopniu odpowiadali, że ból następuje kilka razy w miesiącu - 14 osób $(41,2 \%)$ lub 2-3 razy w tygodniu - 12 osób (35,3\%). Najmniej badanych wskazało, że raz w tygodniu -3 osoby $(8,8 \%)$ (Tabela 4$)$.

Tabela 4. Częstotliwość występowania dolegliwości bólowych kręgosłupa wśród badanych.

\begin{tabular}{|l|l|l|l|l|l|l|}
\hline & \multicolumn{2}{|l|}{ oddział } & \multicolumn{2}{l|}{ zachowawczy } & \multicolumn{2}{l|}{ razem } \\
\hline częstość & liczba & $\%$ & liczba & $\%$ & liczba & $\%$ \\
\hline codziennie & 4 & 25,0 & 5 & 14,7 & 9 & 18,0 \\
\hline
\end{tabular}




\begin{tabular}{|c|c|c|c|c|c|c|}
\hline $\begin{array}{l}\text { 2-3 razy } \\
\text { w tygodniu }\end{array}$ & 1 & 6,3 & 12 & 35,3 & 13 & 26,0 \\
\hline raz w tygodniu & 1 & 6,3 & 3 & 8,8 & 4 & 8,0 \\
\hline $\begin{array}{l}\text { kilka razy } \\
\text { w miesiącu }\end{array}$ & 10 & 62,5 & 14 & 41,2 & 24 & 48,0 \\
\hline Razem & 16 & 100,0 & 34 & 100,0 & 50 & 100,0 \\
\hline
\end{tabular}

Źródło: wynik badań własnych

Określając natężenia bólu na skali wzrokowo - analogowej VAS, najwięcej badanych wskazało na ocenę „5" - 13 osób $(26,0 \%)$. Respondenci wskazali również na ocenę "6" - 10 osób (20,0\%) oraz ocenę "4" - 9 osób (18,0\%). Najmniej respondentów wskazało na ocenę "1" i „8” - po 2 osoby (po 4,0\%) oraz na ocenę „9" - 1 osoba $(2,0 \%)$. Żadna z osób badanych nie wskazała na oceny skrajne „0”, jako brak bólu oraz ocenę „10”, jako najsilniejszy ból (Tabela 5).

Tabela 5. Wyniki skali VAS dotyczące doświadczania dolegliwości bólowych kręgosłupa lędźwiowo-krzyżowego u badanych.

\begin{tabular}{|l|l|l|l|l|l|l|l|l|l|l|l|}
\hline skala & $\begin{array}{l}\mathbf{0} \\
\text { /brak } \\
\text { bólu/ }\end{array}$ & $\mathbf{1}$ & $\mathbf{2}$ & $\mathbf{3}$ & $\mathbf{4}$ & $\mathbf{5}$ & $\mathbf{6}$ & $\mathbf{7}$ & $\mathbf{8}$ & $\mathbf{9}$ & $\begin{array}{l}\mathbf{1 0} \text { /najsilniejszy } \\
\text { ból/ }\end{array}$ \\
\hline $\begin{array}{l}\text { Liczb } \\
\text { a }\end{array}$ & 0 & 2 & 4 & 3 & 9 & 13 & 10 & 6 & 2 & 1 & 0 \\
\hline$\%$ & 0,0 & $\begin{array}{l}4, \\
0\end{array}$ & 0 & $\begin{array}{l}6, \\
0\end{array}$ & $\begin{array}{l}18, \\
0\end{array}$ & $\begin{array}{l}26 \\
0\end{array}$ & $\begin{array}{l}20, \\
0\end{array}$ & $\begin{array}{l}12, \\
0\end{array}$ & $\begin{array}{l}4, \\
0\end{array}$ & $\begin{array}{l}2, \\
0\end{array}$ & 0,0 \\
\hline
\end{tabular}

Źródło: wynik badań własnych 
Średnia ocena odczuwanego bólu według skali VAS wyniosła 4,97 punktu. Wyższą średnią odnotowano wśród respondentów w oddziale zachowawczym - 5,15 punktu, przy średniej - 4,59 punktu w oddziale zabiegowym. Wynik wśród badanych był minimalny oraz zbliżony na obu oddziałach, niższy uzyskano u respondentów pracujących na oddziale zabiegowym (1 punkt), wyższy uzyskano u ankietowanych z oddziału zachowawczego ( 9 punktów). Ze względu na poziom istotności $(p>0,05)$ nie odnotowano statystycznie istotnej różnicy wśród respondentów z poszczególnych oddziałów (Tabela 6).

Tabela 6. Typ oddziału a odczuwanie dolegliwości bólowych kręgosłupa.

\begin{tabular}{|c|c|c|c|c|c|c|c|c|c|}
\hline $\begin{array}{l}\text { Sum.ra } \\
\text { ng } \\
\text { zabieg. }\end{array}$ & $\begin{array}{l}\text { Sum.ra } \\
\text { ng } \\
\text { zachow } \\
\text {. }\end{array}$ & $\mathbf{U}$ & $\mathbf{Z}$ & $\begin{array}{l}\text { poziom } \\
\text { p }\end{array}$ & $\begin{array}{l}\text { Z } \\
\text { popra } \\
\text { w }\end{array}$ & $\begin{array}{l}\text { poziom } \\
\text { p }\end{array}$ & $\begin{array}{l}\text { N } \\
\text { ważn. } \\
\text { zabie } \\
\text { g. }\end{array}$ & \begin{tabular}{|l}
$\mathbf{N}$ \\
ważn. \\
zacho \\
w.
\end{tabular} & $\begin{array}{l}2^{*} 1 \mathrm{~s} \\
\operatorname{tr} \\
\text { dokt. } \\
\text { p. }\end{array}$ \\
\hline 373,5 & 901,5 & $\begin{array}{l}237 \\
5\end{array}$ & $\begin{array}{l}- \\
0,70 \\
7\end{array}$ & 0,480 & $-0,718$ & 0,473 & 16 & 34 & $\begin{array}{l}0,47 \\
7\end{array}$ \\
\hline
\end{tabular}

* Test U Manna-Whitneya

Źródło: wynik badań własnych

Najwyższą średnią odczuwania bólu wśród respondentów odnotowano w grupie wiekowej powyżej 50 lat - 5,74 punktu, a najniższą $\mathrm{u}$ ankietowanych $\mathrm{w}$ grupie wiekowej do 40 lat - 4,06 punktu. Wiek badanych oraz wykształcenie, pozostawało $\mathrm{w}$ istotnej statystycznie korelacji $(\mathrm{p}<0,05)$, odpowiednio średniej oraz niskiej korelacji, z wynikami odczuwanego bólu w skali VAS w odniesieniu do wszystkich respondentów oraz badanych z oddziału zabiegowego (Tabela 7). 
Tabela 7. Wiek i wykształcenie a odczuwanie dolegliwości bólowych kręgosłupa.

\begin{tabular}{|l|l|l|l|l|}
\hline & N & R & t(N-2) & poziom p \\
\hline Wiek & 50 & 0,313 & 2,280 & 0,027 \\
\hline razem & 16 & 0,641 & 3,127 & 0,007 \\
\hline zabiegowy & 34 & 0,109 & 0,618 & 0,541 \\
\hline zachowawczy & \multicolumn{5}{|l|}{} \\
\hline Wykształcenie & 50 & $-0,296$ & $-2,145$ & 0,037 \\
\hline razem & 16 & $-0,641$ & $-3,123$ & 0,007 \\
\hline zabiegowy & 34 & $-0,115$ & $-0,655$ & 0,517 \\
\hline zachowawczy & \multicolumn{5}{|l|}{} \\
\hline
\end{tabular}

*rang Spearman test

Źródło: wynik badań własnych

Ze względu na poziom istotności $(\mathrm{p}>0,05)$ nie odnotowano statystycznie istotnej korelacji pomiędzy miejscem zamieszkania, a nasileniem dolegliwości bólowych (Tabela 8).

Tabela 8. Miejsce zamieszkania, a dolegliwości bólowe kręgosłupa.

\begin{tabular}{|c|c|c|c|c|c|c|c|c|c|c|}
\hline $\begin{array}{l}\text { pozyc } \\
\text { ja }\end{array}$ & $\begin{array}{l}\text { Sum.r } \\
\text { ang } \\
\text { miasto }\end{array}$ & 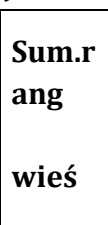 & $\mathbf{U}$ & $\mathbf{Z}$ & $\begin{array}{l}\text { pozio } \\
\text { m p }\end{array}$ & $\begin{array}{l}\text { Z } \\
\text { popr } \\
\text { aw }\end{array}$ & $\begin{array}{l}\text { pozio } \\
\text { m p }\end{array}$ & $\begin{array}{l}\mathbf{N} \\
\text { ważn } \\
\text { miast }\end{array}$ & $\begin{array}{l}\mathbf{N} \\
\text { ważn } \\
\text { wieś }\end{array}$ & $\begin{array}{l}\begin{array}{l}2 * 1 s \\
\operatorname{tr}\end{array} \\
\text { dokł } \\
\text {.p. }\end{array}$ \\
\hline
\end{tabular}




\begin{tabular}{|l|l|l|l|l|l|l|l|l|l|l|}
\hline & & & & & & & & o & & \\
\hline $\begin{array}{l}\text { raze } \\
\text { m }\end{array}$ & 902,5 & 372,5 & $\begin{array}{l}236 \\
5\end{array}$ & $\begin{array}{l}0,7 \\
28\end{array}$ & 0,467 & 0,740 & 0,460 & 34 & 16 & $\begin{array}{l}0,46 \\
4\end{array}$ \\
\hline $\begin{array}{l}\text { Zabie } \\
\text { g. }\end{array}$ & 91,0 & 45,0 & $\begin{array}{l}24, \\
0\end{array}$ & $\begin{array}{l}0,5 \\
97\end{array}$ & 0,551 & 0,608 & 0,543 & 10 & 6 & $\begin{array}{l}0,56 \\
2\end{array}$ \\
\hline $\begin{array}{l}\text { Zacho } \\
\text { w. }\end{array}$ & 428,0 & 167,0 & $\begin{array}{l}112 \\
, 0\end{array}$ & $\begin{array}{l}0,2 \\
83\end{array}$ & 0,777 & 0,289 & 0,773 & 24 & 10 & $\begin{array}{l}0,78 \\
0\end{array}$ \\
\hline
\end{tabular}

* Test U Manna-Whitneya

Źrodło: wynik badań własnych

\section{Dyskusja}

Zespoły bólowe kręgosłupa są obecnie głównymi problemami w sferze ekonomiczno-społecznej oraz medycznej funkcjonowania społeczeństw. Współcześnie traktowane są jako choroba cywilizacyjna [2].

Zawód pielęgniarki związany jest $\mathrm{z}$ obciążeniem statycznym kręgosłupa oraz jego przeciążeniami w czasie wysiłku fizycznego. Dolegliwości bólowe odcinka lędźwiowo-krzyżowego wśród personelu pielęgniarskiego bez wątpienia wiążą się z charakterem wykonywanej pracy [6]. Do kluczowych przyczyn, sprzyjających wystąpieniu możemy zakwalifikować: dźwiganie, niewłaściwą pozycję siedzącą, podnoszenie, brak ruchu oraz stres. Utrwalanie nieprawidłowo wykonywanych czynności oraz nieprawidłowych nawyków doprowadza do pojawienia się nagłego bólu oraz do zmian przeciążeniowych [7].

W przeprowadzonym badaniu wszyscy respondenci (100\%) deklarują, iż doświadczają dolegliwości bólowych kręgosłupa. Ponad połowa badanych wskazała, że najczęściej odczuwany jest przez nich ból w odcinku lędźwiowym kręgosłupa - 30 osób (60,0\%), natomiast 
ból w odcinku krzyżowym kręgosłupa deklaruje 20 osób (40,0\%). Z kolei w badaniach przeprowadzonych przez Frey i wsp. [8] wśród 50,8\% pielęgniarek występował przewlekły ból kręgosłupa. Natomiast Suliman [9] w swoich badaniach wskazała na występowanie dolegliwości bólowych ze strony kręgosłupa u 265 pielęgniarek, tj. 69\%. Podobne wyniki uzyskano w opracowaniu Nourollahi i wsp. [10], gdzie wśród 72\% pielęgniarek odnotowano ból w odcinku krzyżowym kręgosłupa. Z kolei $\mathrm{w}$ badaniach przeprowadzonych przez Abolfotouh i wsp. [11] wykazano, iż na dolegliwości bólowe kręgosłupa raz do roku uskarża się blisko $54,3 \%$ pielęgniarek, a kolejne $26,8 \%$ określa ból jako przewlekły.

W przeprowadzonych przez nas badaniach wykazano, że wiek badanych pozostawał $\mathrm{w}$ istotnej statystycznie zależności z występowaniem zespołów bólowych kręgosłupa lędźwiowokrzyżowego $(\mathrm{p}<0,05)$. Nie odnotowano statystycznie istotnej różnicy pomiędzy odczuwaniem zespołów bólowych kręgosłupa w odcinku lędźwiowo-krzyżowym w całej badanej grupie pielęgniarek, jak i ze zględu na ich zatrudnienie $w$ poszczególnych oddziałach oraz miejsca zamieszkania badanych.

Badane osoby zostały podzielone pod względem wykształcenia na dwie grupy: osoby, które ukończył szkoły średnie oraz absolwentów studiów wyższych. Wykazano istotną statystycznie zależność między występowaniem zespołów bólowych kręgosłupa w odcinku lędźwiowo-krzyżowym, a posiadanym wykształceniem badanych pielęgniarek. Odczuwanie bólu częściej zgłaszały pielęgniarki $\mathrm{z}$ wykształceniem średnim niż $\mathrm{z}$ wykształceniem wyższym. Z kolei G. Jaroszewicz twierdzi, że dolegliwości w układzie mięśniowo-szkieletowym wynikają $\mathrm{z}$ czasu pracy oraz często z czynników, które są związane z pozazawodową aktywnością oraz wpływu środowiska pracy. Mają także związek $\mathrm{z}$ cechami indywidualnymi takimi jak: płeć, wiek, aktywność fizyczna, stres [12]. Eriksen [13] w swoich badaniach potwierdził, że w ciągu pracy zawodowej 88,8\% pielęgniarek w wieku powyżej 50 lat doświadczyło 
ostrego bądź przewlekłego zespołu bólowego kręgosłupa. Wyderka M. oraz Niedzielska T. [14] badaniami objęły 100 pielęgniarek, zatrudnionych $\mathrm{w}$ oddziałach neurologii oraz interny, których średnia wieku wynosiła powyżej 40 r.ż. Wykazano, że właśnie wiek wpływa na obniżenie o 10-40 \% zdolności do wykonywania wysiłku fizycznego oraz zmniejsza zdolności regeneracyjne organizmu. Kraunayake i wsp. [15] również badali czynniki, które istotnie wpływają na występowanie przewlekłego bólu pleców. Autorzy ustalili, że wpływ na powyższe dolegliwości mają: znajomość profilaktyki, poziom wykształcenia, aktywność fizyczna, spożywanie alkoholu oraz białka zwierzęcego, występowanie w rodzinie bólów kręgosłupa [85]. Wyderka M. oraz Niedzielska T. [14] w badaniach poświęconych ergonomii pracy pielęgniarek wykazały, że co czwarta z nich nie miała czasu na szkolenia $\mathrm{w}$ tym zakresie. Wykazano, że najbardziej obciążającymi czynnościami układ ruchu to nieprawidłowy sprzęt medyczny oraz niewystarczająca wiedza na ten temat.

\section{Wnioski}

1. Wszystkie badane osoby na obu oddziałach stwierdziły zgodnie, że doświadczają dolegliwości bólowych kręgosłupa. Średnia ocena odczuwania bólu przez badanych według skali VAS wyniosła 4,97 punktu.

2. Jako najczęściej występujący charakter bólu wskazano ból promieniujący - 46 osób, (33,3\% wszystkich zaznaczonych stwierdzeń). W dalszej kolejności zaznaczano ból rwący - 32 osoby $(23,2 \%)$ oraz ból przeszywający - 23 osoby $(16,7 \%)$.

3. Blisko 48,0\% respondentów odpowiedziało, iż ból kręgosłupa w odcinku lędźwiowo-krzyżowym występuje kilka razy w miesiącu.

4. Wiek badanych oraz wykształcenie, pozostawało $\mathrm{w}$ istotnej statystycznie korelacji $(\mathrm{p}<0,05) \mathrm{z}$ wynikami odczuwanego bólu w skali VAS. 


\section{Zalecenia dla praktyki pielęgniarskiej}

Jedną $\mathrm{z}$ najbardziej narażonych grup zawodowych na występowanie dolegliwości bólowych kręgosłupa są pielęgniarki/pielęgniarze. Częstym powód bólu, który jest odczuwany przez pielęgniarki, stanowi osłabiony oraz nieprawidłowo przygotowany mięśniowo-więzadłowy aparat, dlatego tak istotna jest profilaktyka zespołów bólowych. Ważnym czynnikiem, który pomaga w zmniejszeniu dolegliwości spowodowanych przeciążeniem kręgosłupa są systematyczne ćwiczenia. Istotne jest także stosowanie w przebiegu leczenia dolegliwości bólowych takich zabiegów jak: ciepłolecznictwo, elektroterapia, krioterapia, magnetoterapia, laseroterapia oraz ultradźwięki.

\section{Bibliografia/Bibliography:}

1. Morton M. Zespoły bólowe kręgosłupa. Przew Lek. 2008;5:45-55.

2. Wójcik A, Martowicz B. Zespoły bólowe odcinka lędźwiowokrzyżowego. THINK. 2012;2(10):50-63.

3. Milanow J. Zespół bólowy kręgosłupa. Pediatr Med Rodz. 2014;10(3):253-264.

4. Świątkowska B. Dolegliwości bólowe kręgosłupa- przyczyny i zapobieganie. Prewen Rehabilit. 2000;4:7-10.

5. Wordliczek J., Dobrogowski J. Leczenie bólu. Wyd. PZWL, Warszawa 2011.

6. Leszczyńska A., Daniszewska B., Dudek K., Chrzanowska-Rydz M. Szmagaj J., Kujawa J. Wpływ ergonomii pracy pielęgniarek na występowanie dolegliwości bólowych $\mathrm{w}$ obrębie kręgosłupa. Kwart Ortop. 2008;2:210-218. 
7. Spannbauer A., Danek J. Czy bóle pleców to też twój problem? Kilka uwag praktycznych dla pielęgniarki i rehabilitanta jak troszczyć się o swój kręgosłup. Pielęg Chir Angiol. 2008;4(2):129-35.

8. Frey D., Rieger S., Diehl E., Pinzon L.C.E. Factors Influencing Chronic Back Pain in Care Workers Attending to The Elderly in Germany. Gesundheitswesen. 2018;80(2):172-175.

9. Suliman M. Prevalence of low back pain and associated factors among nurses in Jordan. Nurs Forum. 2018;53(4):425-431.

10. Nourollahi M., Afshari D., Dianat I. Awkward trunk postures and their relationship with low back pain in hospital nurses. Work. 2018;59(3):317-323.

11. Abolfotouh S.M., Mahmoud K., Faraj K., Moammer G., ElSayed A., Abolfotouh M.A. Prevalence, consequences and predictors of low back pain among nurses in a tertiary care setting. Int Orthop. 2015;39(12):2439-49.

12. Jarosiewicz G. Jak chronić układ mięśniowo-szkieletowy podczas pracy. Poradnik dla pracowników służby zdrowia PIP. Główny Inspektor Pracy, Warszawa 2010.

13. Eriksen W. The Prevalence od Musculoskeletal Pain in Norwegian Nurses Aides. International archives of occupational enviromental health. 2003;76 (8):625-630.

14. Wyderka M., Niedzielska T. Ergonomia w pracy pielęgniarki. Pielęgniarstwo Polskie. 2016;2(60):165-169.

15. Kraunanayake A., Pathmeswaran A., Kasturiratne A.; Risk factors for chronic low back pain in a sample of suburban Sri Lankan adult males. International Journal of Rheumatic Diseases, 2013, 16 (2), s. 203-210. 